\title{
Antioxidant substances and phytonutrients in sweet potato tubers of different flesh colour
}

\author{
Suchismita Mitra, Surajit Mitra * and J. Tarafdar** \\ Julien Day School, Kalyani-741235, Nadia, West Bengal, India \\ *Dept. of Post Harvest Technology, Bidhan Chandra Krishi Viswavidyalaya (Agril. University), Mohanpur-741252, Nadia, West Bengal, India \\ **ICAR-AICRP on Tuber Crops, Bidhan Chandra Krishi Viswavidyalaya (Agril. University), Mohanpur-741252, Nadia, West Bengal, India
}

\section{Article Info}

Article history

Received 4 July 2021

Revised 26 August 2021

Accepted 27 August 2021

Published online 30 December 2021

\section{Keywords}

Sweet potato

Antioxidant

Phytonutrients

Orange flesh

Purple flesh

\begin{abstract}
Sweet potato tubers combine the properties of cereals, fruits and vegetables owing to its content of starch, pectin and vitamins, respectively. Despite a carbohydrate rich food, sweet potato has low glycemic index. It is now also considered as an antidiabetic food. Depending on the flesh colour, sweet potato tubers are also rich in $\beta$-carotene, anthocyanins and total phenols. An experiment was conducted on sweet potatoes of different flesh colour to establish the relation of tuber flesh colours on the possession of different antioxidant substances along with other phytonutrients, and to identify sweet potato cultivars of different flesh colour having potential for enriching the human diets with antioxidants and other essential nutrients. Antioxidant substances and other nutrition facts of different orange fleshed, purple fleshed and white fleshed sweet potato cultivars were analysed following standard procedures. Significant differences in all the nutritional parameters including antioxidant substances were observed in sweet potatoes of different flesh colour. Marked variation in biochemical constituents among the cultivars of same flesh colour were also observed. Orange fleshed cultivars were found to contain higher amount of $\beta$-carotene ranging from $4.76 \mathrm{mg} / 100 \mathrm{~g}$ to $11.16 \mathrm{mg} / 100 \mathrm{~g}$. The total sugar content varied from 1.36-3.14\% among the cultivars. The dry matter content of tubers ranged between $23.68 \%$ and $34.11 \%$. Among all the cultivars, both the highest carbohydrate $(21.23 \%)$ and starch content $(15.28 \%)$ were recorded in 'Cross-4', a purple fleshed sweet potato. All the purple fleshed sweet potato cultivars were found to contain high anthocyanins ranging from $9.38 \mathrm{mg} / 100 \mathrm{~g}$ to 18.41 $\mathrm{mg} / 100 \mathrm{~g}$. Antioxidant substances were found to be directly related with the tuber flesh colours. This study suggests that increased consumption of orange-fleshed sweet potatoes having high $\beta$-carotene can contribute considerably to alleviate dietary deficiency of vitamin A. Pigmented cultivars of purplefleshed sweet potatoes having high anthocyanins and total phenols, and orange-fleshed sweet potatoes rich in $\beta$-carotene can also act as good sources of antioxidant.
\end{abstract}

\section{Introduction}

Sweet potato (Ipomoea batatas L. Lam) belongs to the family Convolvulaceae and is grown for its fleshy, starchy tubers. Though, a perennial, the crop is grown as an annual crop of 4-5 months. The tubers are generally consumed either by boiling, baking, frying or converting into different value added products. The tender leaves of sweet potato vines are also used as a vegetable in many countries. However, the leaves are generally used as animal feeds, particularly for dairy cattle and goats (Scott, 1992; Lebot, 2009). Due to wide adaptability, high yield, ability to grow in marginal condition, short duration, high nutritional value and sensory versatility in terms of taste, texture, and peel and flesh colour, sweet potato is gaining popularity as a future food security crop (Mitra, 2017).

It is an important root crop of Asia and is now grown all over the world spreading throughout the tropical and subtropical countries.

Corresponding author: Dr. Surajit Mitra

Professor, Bidhan Chandra Krishi Viswavidyalaya (Agril. University), Mohanpur-741252, Nadia, West Bengal, India

E-mail: drsurajitmitra@yahoo.co.in

Tel.: +91-7003656106

Copyright () 2021 Ukaaz Publications. All rights reserved.

Email: ukaaz@yahoo.com; Website: www.ukaazpublications.com
Asia accounts for about $78 \%$ of the world area under this crop and about $92 \%$ of the world production. China is the leading producer of sweet potato in the world. India is one of the leading producers of sweet potato along with China, America, Brazil, Peru, Mexico and Thailand. Sweet potato ranks the seventh most important food crop in the world and fourth most import food crop in tropical countries (FAOSTAT, 2009). In terms of total production in the world among all food crops, it finds a place after wheat, rice, maize, potato, barley and cassava.

Apart from cheap source of energy, the tubers are rich in starch $(10-25 \%)$, sugars $(1.5-3.5 \%)$, dietary fibre $(1.7-2.4 \%)$, minerals like calcium (15-40 mg/100 g), phosphorous $(25-45 \mathrm{mg} / 100 \mathrm{~g})$, potassium (210-430 mg/100 g), magnesium $(15-35 \mathrm{mg} / 100 \mathrm{~g})$ and vitamins like ascorbic acid (7-35 mg/100 g) along with pyridoxine, thiamine, niacin and riboflavin. Sweet potato tubers combine the properties of cereals, fruits and vegetables owing to its content of starch, pectin and vitamins, respectively. Due to very high dietary energy production of about $195 \mathrm{MJ} / \mathrm{ha} / \mathrm{day}$, sweet potato is considered as 'Energy Storehouse of Nature'. Despite a carbohydrate rich food; sweet potato has low glycemic index $(<55)$, and is placed in the list of foods for diabetic people. Depending on the flesh 
colour, sweet potato tubers are rich in $\beta$-carotene, anthocyanins and total phenolic compounds (Mitra, 2014; Padda and Picha, 2007; Ludvik et al., 2004). Therefore, sweet potato has tremendous potential for contributing to the human diets around the world.

Orange-fleshed sweet potato is now gaining importance among the tropical tuber crops, which has great possibility for being adopted as a regular diet of the consumer food chain to tackling the problem of vitamin A deficiency. Being rich in $\beta$-carotene, the orange-fleshed sweet potato is also gaining importance as the cheapest source of antioxidant having several physiological attributes like antioxidation, anticancer and protection against liver injury, and is most suiting as biofortified crop to combat malnutrition. Thus, there is a great possibility of this subsistence crop to supplement as an alternative staple food source in the era of extensive population growth and nutrition crisis. Increased consumption of orange-fleshed sweet potato in either fresh or cooked form can contribute considerably in alleviating dietary deficiency of vitamin A and, thereby combating night blindness (Mitra et. al., 2010).The carotenoid pigments give orange-fleshed sweet potatoes their distinctive colours.

Of late, there has been increasing interest in purple-fleshed sweet potato also due to the high anthocyanin and total phenol content. Diacylatedanthocyanins isolated from the storage roots of a purplefleshed sweet potato 'Ayamurasaki', were identified to possess a postprandial antihyperglycemic (antidiabetic) effect in rat through retardation of maltase activity. Anthocyanins and phenolic acids have also been reported to possess potential cancer chemopreventive effects. Anthocyanin-rich purple fleshed sweet potato has also been reported to reduce the risk of life-style related diseases, including cancer (Khalid et al., 2017). Dietary phenolic compounds have been recognized by the board of nutrition in the United States as an important health-promoting agent. In addition to being potent antioxidants, phenolic compounds are also able to bind to cellular receptors and transporters, which consequently influence gene expression, cell signaling and cell adhesion. The capability of phenolic compounds to scavenge free radicals is the primary mechanism where phenolic compounds protect the cells from free radical attack. Because of the protective effect of anthocyanins against chronic diseases, different types of food processing methods have been designed to preserve the bioavailability of anthocyanins in sweet potatoes. In Japan, the purple fleshed "Ayamurasaki" extract has been observed in vitro to be a potent antioxidant or radical scavenger, and angiotensin I converting enzyme inhibitor. It was also reported from a study on rat that purple-fleshed "Ayamurasaki" juice exhibited an ameliorative effect against carbon tetrachloride induced liver injury, and polyacylatedanthocyanins were the leading scavengers among all bioactive compounds found in purple-fleshed sweet potatoes (Suda et al., 2003). Sakai et al., (1009) also reported a purple fleshed sweet potato "Akemurasaki" with high anthocyanin content. As reported by Ishiguro et al. (2007), the main polyphenolic components in purple fleshed cultivars were chlorogenic acid and caffeoylquinic acid. Similar to anthocyanins, phenolic acids have free radical scavenging property. The anthocyanin pigments give purple-fleshed sweet potatoes their distinctive colours also.

Since the discovery of the physiological functionality of sweet potatoes and their predominant anthocyanin pigments, the food industry, primarily in Japan, has incorporated sweet potato as ingredients in processed food products. The demand for food products made from purple-fleshed sweet potato has been increased all over Japan since consumers became aware of the health benefit of consuming bioactive compounds like anthocyanins. The paste and flour from purple fleshed sweet potatoes have been used in many countries for making noodles, bread, jams, chips, confectionery, juice, alcoholic drinks and food dyes. Habtemariam (2019) included sweet potato in the list of crops with growing importance as antidiabetic agents.

However, most of the growers and consumers are not much aware of the nutritive value of orange-fleshed and purple-fleshed sweet potato cultivars. Moreover, the biochemical constituents of sweet potato varies among the cultivars grown in different places. Therefore, assessment of biochemical composition of different cultivars in different places is essential for selecting the cultivars having high nutritive values. Considering all these aspects, assessment of nutritional quality including antioxidant substances of the tubers of different cultivars of orange-fleshed, purple-fleshed and white-fleshed sweet potato were made for selecting promising cultivars having high nutritional quality.

\section{Materials and Methods}

The present experiment was conducted in the laboratory of the department of Post Harvest Technology, Bidhan Chandra Krishi Viswavidyalaya (Agril. University), West Bengal, India during 201920. The experiment was carried out to study the variability in biochemical attributes in fresh tubers of fifteen cultivars, five each of orange-fleshed, purple fleshed and white-fleshed sweet potato.

Fresh tubers of five orange-fleshed, five purple-fleshed and five white-fleshed sweet potato harvested at 120 days after planting were collected from the research field of All India Coordinated Research Project on Tuber Crops, Kalyani Centre, BCKV, West Bengal, India for biochemical analysis.

The experiment was laid out in completely randomized design with three replications for each parameter in different cultivars. The data were analysed statistically following the method as described by Gomez and Gomez (1984).

The analysis of variance table for a single factor CRD was formed for each parameter with the following steps. First, correction factor (C.F.) was calculated by dividing square of grand total $(\mathrm{GT})^{2}$ by total number of observations (rxt). Then, total sum of squares (TSS) was calculated by adding square value of all individual observations for each parameter and subtracting the total value by correction factor. Similarly, treatment sum of squares (TrSS), here cultivar sum of square was calculated by adding square value of total replicated values of all cultivars and by dividing this value by numbers of replication and the subsequent value was subtracted by correction factor. Error sum of squares (ESS) was calculated by subtracting cultivar sum of squares from total sum of squares.

Then, MS (variance) of source of variations was calculated, and finally $\mathrm{F}$ (variance ratio) was calculated by dividing treatment MS by error MS, which was then compared with the F value at $5 \%$. In case of all the parameters studied, $\mathrm{F}$ (variance ratio) was higher than the $\mathrm{F}$ value at $5 \%$ level of significance, indicating significant difference between the cultivar means. To identify the best cultivar 
for a particular parameter, and also to find the significant difference among the cultivars, critical difference (CD) was calculated for each parameter.

Of the fifteen cultivars used in this experiment, five cultivars namely 'Bidhan Jyoti', 'ST-14', 'CIPSWA-2', '362-7' and 'S-594' were orange fleshed; five cultivars namely 'X-134', 'X-140', 'X-24, 'Cross 4' and 'DOP MIX 93-13' were purple fleshed; and 'Bidhan Jagannath', 'BCSP-7', 'TSP-16-8', 'TSP-12-10' and 'TSP-12-12' were white fleshed. The following quality parameters of fifteen cultivars under study were assessed.

Dry matter (\%), Moisture (\%), Total soluble solids (TSS) in ${ }^{0}$ Brix, Carbohydrate content (\%), Starch content (\%), Total sugar content $(\%)$, Ascorbic acid content (mg/100 g), $\beta$-carotene content (mg/100 g), Retinol activity equivalent (RAE), Anthocyanin content (mg/ $100 \mathrm{~g}$ ), Crude protein content (\%, dry weight) and Total phenol content $(\mathrm{g} / 100 \mathrm{~g}$, dry weight $)$

After washing, peeling and shredding, fresh tubers were dried at $60^{\circ} \mathrm{C}$ in mechanical dryer for about $48 \mathrm{~h}$ till the tubers gained constant weight to determine the dry matter content $(\%)$. The dried samples were ground to powder and was pass through a $250 \mu \mathrm{m}$ sieve. The sweet potato powder was then kept in self-sealing pouches at $4^{\circ} \mathrm{C}$ for further analysis. Total soluble solids content was measured by using a Hand Refractometer from the extract of fresh sweet potato tuber. The shadow level of the scale was adjusted to ' 0 ' reading with a drop of distilled water. Subsequently, the water was blotted out with filter paper, the refractometer was air dried and a drop of freshly squeezed juice was placed on the plate (specimen chamber) to record the refractometer reading. The total soluble solids content was expressed in ${ }^{\circ}$ Brix. The ascorbic acid $(\mathrm{mg} / 100 \mathrm{~g}), \beta$-carotene $(\mathrm{mg} / 100 \mathrm{~g})$, carbohydrate $(\%)$, starch $(\%)$, and total sugar content in per cent were determined on the basis of fresh weight following standard procedures. Total carbohydrate was assessed following the procedure as described by Sadasivam and Manickam (1996). Starch and total sugar content of the tubers were estimated following the titrimetric method as described by Moorthy and Padmaja (2002), which involved extraction of sugars with $80 \%$ ethanol. The extract was filtered and the filtrate was used for the analysis of sugars. The residue was acid hydrolysed using $2 \mathrm{~N} \mathrm{HCL}$ for the estimation of starch. The hydrolysates were titrated against $1 \%$ potassium ferricyanide and $2.5 \mathrm{~N} \mathrm{NaOH}$ solution using methylene blue as indicator. The 2, 6-Dichloroindophenol titrimetric method was used for ascorbic acid estimation (Ranganna, 2002). Standard ascorbic acid and metaphosphoric acid (3\%) were used in determining dye factor. The ascorbic acid content was measured by titrimetric method using 2, 6-Dichlorophenolindophenol dye. Determination of $\beta$-carotene was done following the spectrophotometric method (AOAC, 1995). The true form of vitamin A or retinol activity equivalents (RAE) was calculated on the basis of conversion factor suggested by Institute of Medicine, Food and Nutrition Board (2001) considering $12 \mu \mathrm{g} \beta$-carotene is equal to $1 \mu \mathrm{g}$ RAE. Total anthocyanins of the tubers were estimated using optical density (OD) as described by Fuleki and Francis (1968). The method consists of extracting the anthocyanins with ethanol $(95 \%)$ and $1.5 \mathrm{~N}$ hydrochloric acid at a ratio of 85:15 and measuring the O.D. of the extract diluted with the extracting solvent at $535 \mathrm{~nm}$ in a UV-Vis spectrophotometer. The total anthocyanin content was calculated with the aid of the coefficient of extinction (98.2) and taking dilution factor into account.

Table 1: Nutrition facts of sweet potato tubers of different flesh colour

\begin{tabular}{|c|c|c|c|c|c|c|}
\hline Cultivar & $\begin{array}{c}\text { Dry matter } \\
(\%)\end{array}$ & $\begin{array}{c}\text { Moisture } \\
(\%)\end{array}$ & $\begin{array}{c}\text { TSS } \\
\left({ }^{0} \text { Brix }\right)\end{array}$ & $\begin{array}{c}\text { Carbohydrate } \\
(\%)(\text { fw })\end{array}$ & $\begin{array}{l}\text { Starch } \\
(\%)(\mathbf{f w})\end{array}$ & $\begin{array}{c}\text { Total sugars } \\
(\%)(\mathrm{fw})\end{array}$ \\
\hline S-594 & 23.68 & 75.82 & 8.2 & 18.63 & 14.34 & 2.54 \\
\hline $362-7$ & 24.16 & 76.37 & 10.4 & 20.40 & 13.53 & 3.14 \\
\hline CIP SWA-2 & 26.63 & 74.24 & 9.6 & 20.72 & 12.67 & 2.75 \\
\hline BidhanJyoti & 25.76 & 74.52 & 9.8 & 18.19 & 12.52 & 2.69 \\
\hline$X-24$ & 26.39 & 73.61 & 6.8 & 17.37 & 11.68 & 1.80 \\
\hline$X-134$ & 34.11 & 65.89 & 8.2 & 19.67 & 12.94 & 1.94 \\
\hline$X-140$ & 26.17 & 73.83 & 7.6 & 16.58 & 9.51 & 2.41 \\
\hline BCSP-7 & 24.71 & 75.29 & 6.2 & 16.17 & 10.54 & 1.36 \\
\hline TSP $16-8$ & 26.73 & 73.27 & 8.6 & 18.24 & 11.83 & 2.34 \\
\hline TSP $12-10$ & 28.16 & 71.84 & 9.4 & 18.13 & 12.66 & 1.98 \\
\hline TSP $12-12$ & 25.87 & 74.13 & 8.8 & 17.82 & 12.32 & 2.23 \\
\hline Bidhan Jagannath & 26.32 & 73.68 & 9.0 & 18.38 & 11.17 & 2.59 \\
\hline SEM & 0.48 & 0.62 & 0.37 & 0.39 & 0.41 & 0.14 \\
\hline$C D(p=0.05)$ & 1.46 & 1.87 & 1.14 & 1.16 & 1.24 & 0.43 \\
\hline
\end{tabular}

$\mathrm{fw}=$ fresh weight 
Table 2: Protein and antioxidant substances in sweet potato tubers of different flesh colour

\begin{tabular}{|c|c|c|c|c|c|c|}
\hline Cultivar & $\begin{array}{c}\text { Crude } \\
\text { protein } \\
(\%) \quad(d w)\end{array}$ & $\begin{array}{c}\text { Ascorbic acid } \\
(\mathrm{mg} / 100 \mathrm{~g}) \\
(\mathrm{fw})\end{array}$ & $\begin{array}{c}\beta \text {-carotene } \\
(\mathrm{mg} / 100 \mathrm{~g}) \\
(\mathrm{fw})\end{array}$ & $\begin{array}{c}\text { Retinol } \\
\text { activity } \\
\text { equivalent } \\
(\text { RAE) } \\
(\mu \mathrm{g} / 100 \mathrm{~g})\end{array}$ & $\begin{array}{c}\text { Anthocyanin } \\
(\mathrm{mg} / 100 \mathrm{~g}) \\
(\mathrm{fw})\end{array}$ & $\begin{array}{c}\text { Total phenols } \\
\text { (g/100 g) } \\
\text { (dw) }\end{array}$ \\
\hline S-594 & 6.46 & 11.74 & 4.76 & 396.67 & 0.43 & 0.92 \\
\hline $362-7$ & 5.86 & 16.91 & 6.42 & 535.00 & 0.51 & 0.46 \\
\hline CIP SWA-2 & 5.48 & 10.32 & 5.17 & 430.83 & 0.33 & 0.78 \\
\hline ST-14 & 4.12 & 17.94 & 11.16 & 930.00 & 0.61 & 0.84 \\
\hline Bidhan Jyoti & 4.92 & 19.84 & 7.82 & 651.67 & 0.46 & 0.62 \\
\hline$X-24$ & 3.87 & 14.36 & 1.37 & 114.17 & 11.15 & 1.43 \\
\hline$X-134$ & 5.47 & 10.14 & 0.63 & 52.50 & 10.53 & 1.34 \\
\hline$X-140$ & 6.14 & 8.38 & 0.81 & 67.50 & 9.38 & 1.29 \\
\hline Cross- 4 & 5.92 & 15.72 & 1.42 & 118.33 & 18.41 & 1.68 \\
\hline $\mathrm{H}-200$ & 4.37 & 11.13 & 1.12 & 93.33 & 10.17 & 1.39 \\
\hline BCSP-7 & 5.72 & 17.54 & 0.23 & 19.16 & 0.14 & 0.51 \\
\hline TSP-16-8 & 5.19 & 13.68 & 0.47 & 39.17 & 0.18 & 0.48 \\
\hline TSP-12-10 & 6.18 & 16.45 & 0.52 & 43.33 & 0.22 & 0.64 \\
\hline TSP-12-12 & 5.37 & 11.86 & 0.17 & 14.17 & 0.11 & 0.57 \\
\hline Bidhan Jagannath & 6.34 & 18.56 & 3.38 & 281.67 & 0.31 & 0.98 \\
\hline SEM & 0.27 & 1.14 & 1.78 & 51.14 & 3.71 & 0.11 \\
\hline $\mathrm{CD}(\mathrm{p}=0.05)$ & 0.82 & 3.46 & 5.38 & 151.53 & 11.36 & 0.32 \\
\hline
\end{tabular}

fw $=$ fresh weight $; \mathrm{dw}=$ dry weight

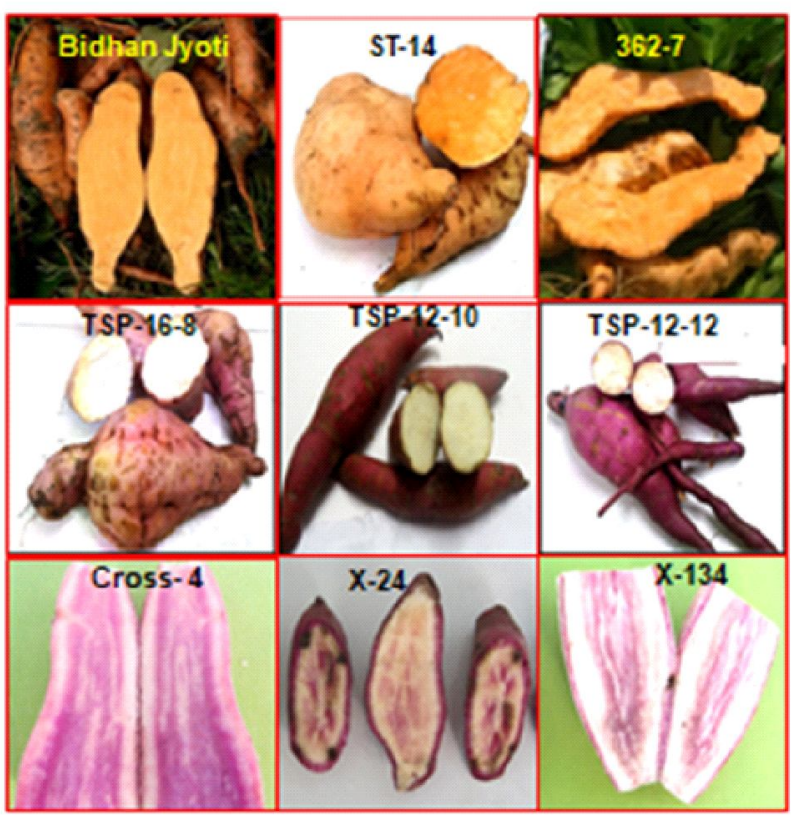

Figure 1: Some orange-fleshed, white-fleshed and purplefleshed sweet potato cultivars.

The estimation of crude protein and phenol content was done on the dry weight basis. Total phenols were estimated following the procedure as described by Swain and Hillis (1955), using sodium carbonate $(20 \%)$, folin- ciocalteau reagent and methanol (80\%). A standard curve was drawn using gallic acid as standard. Different concentrations of gallic acid were prepared and optical density was read at $660 \mathrm{~nm}$ wavelength. The concentration of samples was calculated based on the standard curve. The titrimetric Kjeldahl digestion method as described in AOAC (1995) was used for nitrogen (N) estimation and crude protein content was calculated by multiplying the total nitrogen content with a factor of 6.25 and was expressed in per cent.

\section{Results}

Significant differences in all the nutritional parameters were observed among the cultivars of sweet potato studied. The total soluble solids (TSS) content of the tubers ranged from $6.4{ }^{\circ} \mathrm{Brix}$ in 'BCSP-7', a white fleshed cultivar to $10.4{ }^{\circ} \mathrm{Brix}$ in ' $362-7$ ', an orange fleshed cultivar. Like TSS content, the lowest total sugar content in tubers was also recorded in 'BCSP-7'. The total sugar content was found to vary from 1.36-3.14\% among the cultivars of different flesh colour. The dry matter content of tubers ranged from $23.68 \%$ in 'S-594', an orange fleshed cultivar to $34.11 \%$ in 'X-134', a purple fleshed cultivar. Among all the cultivars, both the highest carbohydrate $(21.23 \%)$ and starch content (15.28\%) were recorded in 'Cross-4', a purple fleshed sweet potato (Table 1). The crude protein content of the cultivars varied between 3.87 and $6.56 \mathrm{~g} / 100 \mathrm{~g}$ of dry powder in ' $\mathrm{X}-24$ ' a purple fleshed cultivar and 'S-594', an orange fleshed cultivar, respectively. The level of total phenols having antioxidant properties varied between 0.46 and $1.68 \mathrm{~g} / 100 \mathrm{~g}$ of dry weight in '362-7' an 
orange fleshed cultivar and 'Cross-4' a purple fleshed cultivar, respectively. Marked variation in ascorbic acid content ranging from 8.38 to $19.84 \mathrm{mg} / 100 \mathrm{~g}$ of fresh tuber was recorded among the cultivars studied. Distinct variations in $\beta$-carotene content among the cultivars of different flesh colour were also observed. Orange fleshed cultivars were found to contain higher amount of $\beta$-carotene ranging from 4.76 $\mathrm{mg} / 100 \mathrm{~g}$ in ' $\mathrm{S}-594$ ' to $11.16 \mathrm{mg} / 100 \mathrm{~g}$ in 'ST-14'. Both the purple fleshed and white fleshed cultivars contained very less or negligible amount of $\beta$-carotene. Among the purple fleshed cultivars, the highest $\beta$-carotene content amounting $1.42 \mathrm{mg} / 100 \mathrm{~g}$ was recorded in Cross- 4 . Whereas, tubers of white fleshed sweet potato, except the yellowish white cultivar 'Bidhan Jagannath' registered the lowest value of $\beta$-carotene. True value of vitamin $A$ in terms of retinol activity equivalents (RAE) was also recorded maximum in orange fleshed cultivars ranging from 396.67 to $930.00 \mu \mathrm{g} / 100 \mathrm{~g}$. Wide variations in anthocyanin content were also observed among the cultivars of different flesh colour. Very less amount of anthocyanin content was recorded in both the orange fleshed and white fleshed cultivars of sweet potato. Unlike orange fleshed and white fleshed cultivars, purple fleshed sweet potato cultivars were found to contain high anthocyanin ranging from $9.38 \mathrm{mg} / 100 \mathrm{~g}$ in ' $\mathrm{X}-140$ ' to $18.41 \mathrm{mg} / 100$ $\mathrm{g}$ in 'Cross-4'. Total phenol content in the tubers was also found to vary significantly among the cultivars. The highest total phenol content of $1.68 \mathrm{~g} / 100 \mathrm{~g}$ of dry weight was recorded in a purple fleshed cultivar 'Cross-4' (Table 2). Both the orange fleshed and white fleshed cultivars witnessed comparatively lower total phenol content as compared to the purple fleshed cultivars of sweet potato.

\section{Discussion}

Among various nutritional parameters, TSS, carbohydrate, starch and ascorbic acid content were not much influenced by the flesh colour of sweet potato. Both higher and lower ranges of these constituents were recorded in the tubers irrespective of flesh colour. Generally, traditional orange-fleshed cultivars contain low dry matter as compared to white-fleshed and purple fleshed cultivars but some of the orange-fleshed cultivars under the study, namely; 'CIPSWA2 ' and 'Bidhan Jyoti' had higher dry matter content of about 26$27 \%$. Orange-fleshed cultivars with higher dry matter content had also been reported earlier (CIP, 2001; Mitra, 2008; Roy et al., 2012; Mitra, 2018). Along with some purple fleshed cultivars like ' $X$ 134' and 'Cross-4', and some white fleshed cultivars like 'TSP-1210 ' and 'TSP 16-8', orange-fleshed cultivars, namely; 'CIPSWA-2' and 'Bidhan Jyoti' having high dry matter can also be used to develop cultivars with higher dry matter content because of the strong consumer preference and industrial demand for cultivars with higher dry matter. Starch was found to be the predominant carbohydrate in all the cultivars, and was directly correlated to the dry matter content of the tubers. Cultivars with higher dry matter registered higher level of starch also. These results are in line with the findings reported by Mitra et al. (2010) and Roy et al. (2012). Mitra et al. (2010) also recorded high starch content of $15.37 \%$ in an orange fleshed sweet potato cultivar which contained high dry matter of $26.52 \%$. The white fleshed cultivar 'BCSP-7' with very low sugar content $(1.36 \%)$ can be used for culinary purpose. Higher protein content was not confined to any specific flesh coloured tubers. Relatively higher protein content of about 6-7\% on dry weight basis was recorded in two each of purple fleshed, orange fleshed and white fleshed cultivars (Table 2). Protein content in this range in orange fleshed cultivars of sweet potato was also reported by Roy et al. (2012). The variation in antioxidant substances were also found among the cultivars of different flesh colour. Like protein content, ascorbic acid content also was not dependent on the flesh colour of tubers. Some cultivars, irrespective of flesh colour contained relatively higher ascorbic acid of about $18-20 \mathrm{mg} / 100 \mathrm{~g}$ of fresh tuber. Mitra (2012) and Rautenbach et al. (2010) also reported similar ranges of ascorbic acid in some orange fleshed sweet potato cultivars. Anthocyanin content was predominant in purple fleshed cultivars. The purple fleshed cultivars studied were light purple in colour, some cultivars had only some purple rings or streaks. Anthocyanin content was positively related with the intensity of purple colour in the tubers. Relatively deep purple fleshed cultivar 'Cross-4' registered the highest anthocyanins content in the tubers. All the purple fleshed cultivars having higher anthocyanins were also found to be superior in total phenol content than the orange fleshed and white fleshed cultivars. Walter et al. (1979) also reported that anthocyanins and chlorogenic acid are the major phenolic compounds present in purple-fleshed sweet potatoes. Purple-fleshed sweet potato has also been reported to have higher antioxidant activity and phenolic content than a certain variety of blueberry, reportedly having exceptionally high levels of antioxidants. Anthocyanins have also been suggested as useful agents in disease prevention by Wang and Stoner (2008) and Cvorovic et al. (2010). The $\beta$-carotene content was directly related with the flesh colour of the tubers. Orange fleshed cultivars were superior in $\beta$-carotene content than both the purple fleshed and white fleshed cultivars. Though, the retinol activity equivalent or true value of vitamin $\mathrm{A}$ in these orange fleshed sweet potato cultivars were lower than that of the orange fleshed cultivars reported by van Jaarsveld et al. (2006), it was quite higher than the level of vitamin A recommended by the Food and Agriculture Organization/World Health Organization (FAO/WHO, 2001).

High dry matter content in tubers enhances conversion of $\beta$-carotene to vitamin $A$, so the $\beta$-carotene in the tubers with high dry matter will be more bioavailable than the orange fleshed cultivars with low dry matter. $\beta$-carotene, the provitamin A from dark orange fleshed sweet potato appears to be more bioavailable than that of the dark green leafy vegetables (Mitra, 2008; Jalal et al., 1998). Increased consumption of orange-fleshed sweet potatoes having high $\beta$-carotene can contribute considerably to alleviate dietary deficiency of vitamin A in the developing countries. Tsou and Hong (1992) also reported that $100-150 \mathrm{~g}$ serving of boiled tubers of orangefleshed sweet potato can supply the daily requirement of vitamin A for young children which can protect them from blindness. Low et al. (2001) and Mitra (2012) also recommended food based approach for increasing consumption of $\beta$-carotene-rich orangefleshed sweet potatoes in alleviating vitamin A deficiency.

\section{Conclusion}

Identified pigmented cultivars of purple-fleshed sweet potatoes having high antioxidant substances like anthocyanins and total phenols, and orange-fleshed sweet potatoes rich in $\beta$-carotene along with moderate total phenols can act as cheap sources of antioxidant. Similarly, white fleshed sweet potatoes with low sugar content can be used for culinary purpose. Large doses of any vitamin or mineral through dietary supplements may affect the body's ability to absorb other nutrients and can be associated with some health risks. So, incorporating both orange fleshed and purple fleshed sweet potatoes with low glycemic index and rich in antioxidants within the diet 
through a food based approach may be regarded as a good choice for promoting health in the challenged situation.

\section{Acknowledgements}

Authors are thankful to the ICAR-All India Coordinated Research Project on Tuber crops, Kalyani Centre, BCKV, West Bengal, India for providing valuable sweet potato cultivars for this study.

\section{Conflict of interest}

The authors declare no conflicts of interest relevant to this article.

\section{References}

AOAC. (1995). Official Methods of Analysis, $16^{\text {th }}$ edition, AOAC International, Washington, DC.

Asadi, K.; Ferguson, L.R.; Philpott, M. and Karunasinghe, N. (2017). Cancerpreventive properties of an anthocyanin-enriched sweet potato in the APC ${ }^{\mathrm{MIN}}$ mouse model. J. Cancer Prev., 22(3):135-146.

CIP. (2001). The VITA A Project: Vitamin A and orange-fleshed sweet potatoes in Sub-Saharan Africa (Internet). Nairobi, Kenya: http:// www.cipotato.org/vitaa/ Publications/Paper_vitaa.pdf).

Cvorovic, J.; Tramer, F.; Granzotto, M.; Candussio, L.; Decorti, G. and Passamonti, S. (2010). Oxidative stress-based cytotoxicity of delphinidin and cyanidin in colon cancer cells. Arch. Biochem. Biophys., 501:151157.

FAOSTAT. (2009). Food and Agricultural Organization Statistical Database: Agriculture Items http:/ /faostat.fao.org.

Fuleki, T. and Francis, F.J. (1968). Quantitative Methods for Anthocyanins 1. Extraction and determination of total anthocyanins in cranberry juice. Journal of Food Science, 33:72-77.

Gomez, K. A. and Gomez, A. A. (1984). Statistical procedure for Agricultural Research, ( $2^{\text {nd }}$ Edition), Wiley- Interscience Publications, John Wiley and Sons, New York.

Habtemariam, S. (2019). Other common and exotic foods with growing importance as antidiabetic agents. Medicinal Foods as Potential Therapies for Type-2 Diabetes and Associated Diseases, Elsevier Ltd., pp:985-1047.

Institute of Medicine, Food and Nutrition Board. (2001). Dietary references intakes for vitamin A, vitamin $\mathrm{K}$, arsenic, boron, chromium, copper, iodine, iron, manganese, molybdenum, nickel, silicon, vanadium, and zinc. USA: National Academy Press, Washington DC.

Ishiguro, K.; Yahara, S. and Yoshimoto, M. (2007). Changes in polyphenolic content and radical-scavenging activity of sweet potato (Ipomoea batatas L.) during storage at optimal and low temperatures. J. Agric. Food Chem., 26:10773-10778.

Jalal, F.; Nesheim; M.C.; Agus, Z.; Sanjur, D. and Habicht, J.P.(1998). Serum retinol concentrations in children are affected by food sources of $\beta$-carotene, fat intake and anthelmintic drug treatment. Am. J. Clin. Nutr., 68:623-629

Lebot, V. (2009). Tropical root and tuber crops: Cassava, sweet potato, yams and aroids. Crop Production Science in Horticulture (17), CAB books, CABI, Wallingford, UK.

Low, J.; Walker, T. and Hijmans, R. (2001). The potential impact of orangefleshed sweet potatoes on vitamin A intake in Sub-Saharan Africa. Paper presented at a regional work shop on food based approaches to human nutritional deficiencies: The VITAA Project, Vitamin A and orange-fleshed sweet potatoes in Sub-Saharan Africa, 9-11 May, Nairobi, Kenya.
Ludvik, B.; Neuffer, B. and Pacini, G. (2004). Efficacy of Ipomoea batatas (Caiapo) on diabetes control in type 2 diabetic subjects treated with diet. Diabetes Care, 27:436-440.

Mitra, Surajit (2018). Nutritional quality and anti-nutritional facts of tropical tuber crops. Lead paper presented in the $17^{\text {th }}$ World Congress on "Nutrition and Food Chemistry" held during September, pp:1315, 2018 at London, UK.

Mitra, Surajit (2017). Tropical tubers as alternate staple crops for food and nutrition security. Proceedings of the International Symposium on "Eco-Efficiency in Agriculture and Allied Research" held at BCKV, Kalyani, West Bengal from January, pp:20-23.

Mitra, Surajit (2014). Potential of sweet potato as a tuber crop for future food and nutrition security. Paper presented in the International Conference on "India Biodiversity Meet-2014" held at Indian Statistical Institute, Kolkata from November, pp:21-23.

Mitra, Surajit (2012). Nutritional status of orange-fleshed sweet potatoes in alleviating vitamin A malnutrition through a food-based approach. J. Nutr. Food Sci., 2(8): 1000160 (Open Access). doi:10.4172/ 2155-9600.1000160

Mitra, Surajit. (2008). Nutritional quality of orange-fleshed sweet potatoes. Paper presented in the 'International Conference - Postharvest Unlimited', November 04-07, Berlin, Germany.

Mitra, S.; Tarafdar, J. and Palaniswami, M. S. (2010). Impacts of different maturity stages and storage on nutritional changes in raw and cooked tubers of orange-fleshed sweet potato (Ipomoea batatas L. Lam) Cultivars. Acta. Hort., 858:5-12.

Moorthy, S. N. and Padmaja, G. (2002). A rapid titrimetric method for the determination of starch content of cassava tubers. J. Root Crops, 28(1):30-37.

Padda, M.S. and Picha, D.H. (2007). Antioxidant activity and phenolic composition changes in sweet potato root and leaf tissue at different growth stages. J. Americ. Soc. Hort. Sci., 132(4):447-451.

Ranganna, S. (2002). Manual of analysis of fruit and vegetable products. Tata McGraw Hill Publishing Company Limited.

Rautenbach, F.; Faber, M.; Laurie, S. and Laurie, R. (2010). Antioxidant capacity and antioxidant contents in roots of 4 sweet potato varieties. Journal of Food Science, 75:400-405.

Roy, S.; Banerjee, A.; Tarafdar, J. and Mitra. S. (2012). Tuber quality assessment of orange-fleshed sweet potato (Ipomoea batatas) cultivars and their genetic relatedness as revealed by SDS-PAGE of tuber proteins. Indian Journal of Agricultural Sciences, 82(6):482-488.

Sadasivam, S. and Manickam, A. (1996). Biochemical Methods, $2^{\text {nd }}$ edition. New Age International Pvt Ltd, New Delhi.

Sakai, T.; Kai, Y.; Katayama, K. and Yoshinaga, M. (2009). New sweet potato cultivar "Akemurasaki" with high anthocyanin content. Sweet Potato-Research-Front, 22:2.

Scott, G. J. (1992). Sweet potato as animal feed in developing countries: present patterns and future prospects. In: Roots, tubers, plantains and bananas in animal feeding. Machin, D. and Nyvold, S. eds, Proc. FAO Expert Consultation held in CIAT, Cali, Colombia 2125 January 1991; FAO Animal Production and Health Paper-95.

Suda, I.; Oki, T.; Masuda, M.; Kokbayashi, M.; Nishiba, Y. and Furuta, S. (2003). Physiological functionality of purple-fleshed sweet potatoes containing anthocyanins and their utilization in foods. Japan Agricultural Research Quarterly, 37(3):167-173. 
Swain, T. and Hillis, W. E. (1955). The phenolic constituents of Prunus domestica $L$. The quantitative analysis of phenolic constituents. J. Sci. Food and Agri., 10(1):63-68.

Tsou, S.C.S. and Hong, T. L. (1992). The nutrition and utilization of sweet potato. Sweet potato technology for the Twenty-first Century, Tuskeegee University Press, Tuskeegee University, USA.

VanJaarsveld, P. J.; Marais, D. W.; Harmse, E.; Nestel, P. and Rodriguez-Amaya, D. B. (2006). Retention of $\beta$-carotene in boiled, mashed orange-fleshed sweet potato. Journal of Food Composition and Analysis, 19: $321-9$.

Walter, W. M.; Purcell, A. E. and McCollum, G. K. (1979). Use of high-pressure liquid chromatography for analysis of sweetpotato phenolics. J Agric Food Chem., 27(5):938-941.

Wang, L. S. and Stoner, G. D. (2008). Anthocyanins and their role in cancer prevention. Cancer Lett., 269:281-290. 